\title{
Models of implementation of the virtual educational environment in the process of teaching
}

\author{
Sergey Kotov ${ }^{1}$, Igor Nefedov ${ }^{1}$, Andrey Panteleev ${ }^{1}$, Nina Kotova ${ }^{2 *}$, and Grigory Kotov ${ }^{1}$ \\ ${ }^{1}$ Southern Federal University, 344006, Rostov-on-Don, Russia \\ ${ }^{2}$ South-Russian Institute of Management of Russian Presidential Academy of National Economy and \\ Public Administration, 344002, Rostov-on - Don, Russia
}

\begin{abstract}
This article deals with the problem of choosing the most optimal teaching model for teaching Russian as a foreign language. The purpose of the research is to identify and analyze possible models for the introduction of a virtual educational environment in the process of teaching Russian as a foreign language, and to determine the criteria for the effectiveness of these models. The article is based on the following practical methods: observation of classroom and extracurricular communication between teachers and foreign students, questioning of teachers and students, the method of experiment. Five models of the introduction of virtual educational environment into the practice of teaching Russian as a foreign language are identified and analyzed, and the functional capabilities of platforms and applications used in online learning are described in detail. The main problems that arise for foreign students while fully converting Russian language teaching into a distance format are identified. Russian language teaching quality is determined by three main criteria that affect the quality of teaching Russian to foreign students in a distance format using a virtual educational environment: the level of Russian language proficiency, the motivation of the student, and the language/discipline section being studied. The mixed learning model, which combines traditional classroom learning with parallel online broadcasting of classes in a virtual space, is currently the most optimal model for implementing a virtual educational environment in the teaching process. When using the mixed learning model, the necessary competencies are acquired by both students studying in the classroom and those students who, due to various circumstances, study in a distance format. The mixed education model allows the student to make a deliberate choice between traditional and innovative models, making it possible to switch from one model to another directly in the learning process.
\end{abstract}

\section{Introduction}

In the 21 st century, various distance learning systems are emerging and actively spreading. The virtual educational environment created with their help in teaching Russian to

\footnotetext{
* Corresponding author: kotova@yandex.ru
} 
foreigners is mainly used as an additional means of teaching within the traditional classroom or class-based education system. It intensifies the educational process, increases its effectiveness, makes it interactive, allows you to realize the creative personal potential of students, build an individual learning pathway.

The analysis of the numerous advantages of using the virtual educational environment in the higher education system and in the course of teaching a foreign language becomes the object of many scientific studies by both foreign and domestic specialists [1]. The virtual educational environment "simplifies the acquisition of education by socially vulnerable segments of the population [2]", "contributes to the accumulation of intellectual and economic potential of strategic resources that ensure the sustainable development of society [3]". Professor A. I. Gorozhanov in his monograph "Virtual Learning for Learning a Foreign Language: the Problem of Development and Working" very objectively and thoroughly examines the prospects for using the virtual learning environment in higher education, determines its suitability for learning a foreign language, talks about the role of students and teachers in the virtual learning environment, considers the parameters of its interface and software development tools with specific examples [4]. A group of English scientists led by professor Southgate from the University of Newcastle notes the high efficiency "of the use of IVR technology in teaching schoolchildren in classrooms using a virtual educational environment [5]". According to the Russian researchers I. V. Dokukina and $\mathrm{Yu}$. L. Gumanova, the prospects of using virtual chatbots in teaching a foreign language are quite high, since such chatbots "are available 24 hours 7 days a week on the student's own mobile device and are able to provide training at a convenient time, in a convenient place and in small portions or short fragments, which is well suited for the rapidly developing life of modern students [6]".

Currently, there is a large-scale implementation of distance learning systems at various levels and stages of educational systems all over the world. Systems such as Moodle [7], Zoom [8], Microsoft Teams [9], ISpring Learn [10], Teachbase, E-Stages and many others are undergoing global testing. Teaching a foreign language completely in a virtual educational environment possesses not only the advantages listed above, but also has certain disadvantages. Thus, Patricia Aguilera-Hermida, based on a study conducted among students from universities on the east coast of the United States, makes a disappointing conclusion that "although the rate of ICT usage has increased after the transition of the learning process to a virtual educational environment, motivation level, self-awareness and cognitive involvement of students have decreased [11]". Professors Maclntyre P.D., Gregersen T., Mercer S. have reasonably pointed out that "learning in a virtual educational environment can have a negative impact not only on students, but also on teachers. During the Covid-19 pandemic, the shift to online learning has erased the boundaries between work and home, leading to frequent stress among faculty members [12]". According to Professors Lin and Warshauer, "learning a foreign language with the help of exclusively virtual communication leads to an insufficient degree of formation of students' communicative competence [13]". A group of Mizoram University teachers from India believes that "all the shortcomings of the virtual educational environment identified in 2020 will allow creating a new platform and special programs that will be more effective than the existing ones at the moment [7]".

The purpose of this study is to present and analyze possible models for the introduction of a virtual educational environment in the process of teaching Russian as a foreign language (hereinafter - RFL-teaching), to determine the criteria for the efficiency of these models and to present the results of an experiment in using various models in the practice of RFL-teaching at the Southern Federal University, Russian Federation. 


\section{Materials and Methods}

The study used theoretical methods, in particular, the method of comparative and contrastive analysis and synthesis, deductive, the method of perspective modeling of the educational environment, the method of experiment. In addition, the work is based on the following practical methods: monitoring classroom and extracurricular communication between teachers and foreign students, interviewing teachers and students, as well as summarizing personal practical experience in distance learning using a virtual educational environment. A pilot study, including the installation, training and control stages, was conducted at the Southern Federal University in 2020. This study involved 176 foreign students studying at the Institute of Philology, Journalism and Intercultural Communication of the SFU, as well as at the preparatory faculty of the SFU. The research material is based on online learning platforms, virtual learning environment services, and promising models for implementing virtual learning environments in RFL-teaching using online and offline learning.

\section{Results}

The 20th century was the era of scientific and methodological justification, dissemination and implementation of the main methods of RFL-teaching. The main means of teaching was a textbook, and later - an educational and methodological complex. Printed educational and methodological literature has become the basis of the process of teaching Russian to foreign citizens. In the second half of the 20-th century, technological progress led to the emergence of a number of new information carriers, which are also used in teaching a foreign language. Audio and video recordings in various media are increasingly being used in classes for teaching Russian as a foreign language, and audio-lingual and audio-visual methods of RFL-teaching are appearing and gaining wide popularity.

At the very end of the 20th century, there is a transition from the use of audio and video materials to multimedia resources and hypertexts. Multimedia whiteboards, computers, laptops, and Internet resources are increasingly being used by RFL-teachers, and traditional forms of work are being combined with innovative multimedia ones.

In the 2000s, RFL-teachers first fragmentally, and then increasingly started using the resources of the virtual educational environment in the framework of traditional classroom studies, developed the first multimedia theoretical and practical courses on RFL and its teaching methods. The use of a virtual educational environment, formed with the help of computer and mobile technologies, allows you to realize one of the main tasks-learning without borders, anywhere and at any time. "In the 2010s, modern mobile phones and tablets are gradually replacing desktop PCs and making the process of acquiring new knowledge exciting, bright, dynamic and individual. In the context of teaching in the language environment and outside of it, new horizons and educational prospects open up for the teachers of the Russian Language Academy, which can radically change the learning process for the better [14, pp. 175-176]".

In recent years, many definitions of the concept of "virtual educational environment" have appeared in modern scientific and methodological literature. According to one of the most precise definitions, which we will adhere to in this study, the virtual educational environment is "a kind of technical, technological, content and organizational "platform" that various electronic educational, applied resources, tools, including communication tools, allowing to organize the interaction of both constantly contacting and separated by space and time subjects of learning [15]". 
"A virtual educational environment can be built with the help of universal control systems, such as Moodle, or with the help of a set of different services, which can be represented as the following nuclear-peripheral structure [16, p. 67]':

Working in a particular distance learning system depends on the choice made by the educational institution. According to the team of researchers, "the problem of choosing a platform is crucial and depends on a number of factors: what requirements are imposed on the environment, what functional characteristics should be present, what users the environment is focused on, and, importantly, what means you have to purchase and support the required platform $[7$, p.10]".

In most cases, the financial factor becomes the decisive factor, so many educational institutions prefer to make use of open-access distance learning systems. That is why one of the most popular and widely used platforms in the world is Moodle. It has a sufficient set of various tools to ensure the learning process in a distance format using a virtual educational environment. The process of preparing a teacher to work in the Moodle system is quite simple: it can be either short-term advanced training courses, or independent training using the help system. As a result, each trained specialist will be able to create their own virtual program of the discipline and a fund of evaluation tools, fill them with the necessary diverse content. Currently, the Moodle platform is used in thousands of educational institutions of various levels around the world.

The Moodle platform is perfect for teaching Russian to foreign students, for conducting courses on the methodology of teaching Russian language courses for future teachers, and for advanced training courses for practicing specialists. On the basis of the Institute of Philology, Journalism and Intercultural Communication of the Southern Federal University, we have organized and successfully conducted advanced training courses under the program "Current problems of Russian Language Teaching Methods", intensive courses of modern Russian for foreign students in the amount of 36 and 72 hours. The courses involved a combination of contact work and work in a remote format with the use of webinars, multimedia presentations, self-study of various multimedia content, online consultations, project assignments and testing.

As an example of an intensive course of modern Russian, which was implemented both in the contact mode and completely online using the Moodle platform with a combination of other virtual educational environment services (Instagram, Youtube, etc.), we can cite the intensive "Russian as a foreign language. A1" for foreign students who are beginning to learn Russian and want to master it at an elementary level.

In contrast to the traditional format of implementing an intensive course with the help of classroom contact work, conducting this course in a remote format involved multimedia lectures and practical classes online, virtual excursions, and online testing.

Over the past decade, "elements of the virtual educational environment have been used both in the classroom and in extracurricular work in various RFL-courses [17, 18, 19]". Russian courses allowed us to intensify the educational process and train highly professional teachers of Russian as a foreign language, who are able to effectively teach Russian both in Russia and abroad.

Thus, the virtual educational environment in the Institute of Philology, Journalism and Intercultural Communication of the Southern Federal University was used in the RFLtraining in the framework of advanced training courses, summer schools and as an additional means of intensifying the educational process in the context of the implementation of the traditional classroom learning model.

In March 2020, due to the Covid-19 pandemic, the educational process at Southern Federal University was transferred to a distant format on the Microsoft Teams platform. The traditional classroom contact model of learning has been replaced by an innovative one-learning in a virtual educational environment. Lectures and practical classes, 
consultations, tests, exams, and defense of final qualifying works were held according to an electronic schedule in an online format.

A set of Microsoft Office 365 applications allowed to continue the educational process in the virtual space and successfully complete the academic year:

- Word (allowed to create original teaching online documents on ready templates, for example, the leaves of the tasks for the week for practical classes, lectures, plans, sheets of self-knowledge, and more. etc.).

- Excel (allowed to create a semester calendar of classes, class schedules, lists, study groups, timelines, to-do lists, group projects).

- PowerPoint (allowed to create multimedia presentations of lectures, present tasks performed by students, using graphic objects, images, photos, audio and video materials, and visualized effects).

- Outlook (allowed effectively organize training contacts by email, organize the exchange of mail within individual training groups).

- OneDrive (allowed to share scientific and educational materials in various formats using the cloud space).

- OneNote (allowed to create notebooks for individual consultations of students, checking completed assignments).

- SharePoint (allowed to create special sites for each training group and fill them with all the necessary information).

- Teams (allowed to create training teams, conduct lectures and practical online classes, consultations, exams).

- Stream (allowed to create video recordings of lectures and practical classes and consultations and share them with all participants of the educational process).

- Forms (allowed to organize online testing of students).

The testing process of the distance learning model with the use of a virtual educational environment in the RFL-teaching course revealed both a number of advantages and disadvantages. We believe, the positive and negative aspects of this model largely depend on the teacher's training, discipline, student body and level of Russian language proficiency.

Russian language education was most successfully conducted in the framework of the discipline "E-learning and M-learning in Russian language teaching" with undergraduatesphilologists, future teachers of the Russian language, first and second years of study with a high level of Russian language proficiency (C1-C2). Undergraduates quickly mastered all the services of Microsoft Office 365 (work in which is considered within the framework of this discipline) and actively worked in practical classes throughout the semester. It should be noted that within the framework of this discipline, topics that are convenient for studying in a distant format using a virtual educational environment are considered:

1. "Multimedia textbooks in RFL-teaching.

2. Courses of video lectures and audio lectures on RFL-teaching.

3. Internet resources in RFL-teaching.

4. Structure and content of educational websites and platforms for RFL-teaching.

5. The possibilities of social networks Facebook and VKontakte in the RFL-teaching. Specialized social networks for learning foreign language.

6. Computer testing: online and offline.

7. Google Play and App Store mobile apps for RFL-teaching.

8. Messengers and their potential in RFL-teaching.

9. The use of Twitter and Instagram in RFL-teaching.

10. E-mail, SMS, chats and forums in the RFL-teaching.

11. Training videos. YouTube's capabilities in RFL-teaching.

12. Virtual study tours in the RFL-teaching course [18, p. 189]". 
The survey showed that many undergraduates (more than $83 \%$ of respondents) see the advantages of studying in this format, pointing to the savings in personal time, connecting to classes from different locations, and the opportunity to study the specifics of RFLteaching using computer and mobile technologies.

Bachelor-philologists, future teachers of the Russian language, as well as undergraduates, successfully completed training in the spring semester of 2020 in a distance format using a virtual educational environment. However, undergraduate students, unlike undergraduates, were more likely to encounter difficulties in the course of studying various sections of the Russian language and its teaching methods. First of all, various difficulties were caused by a lower level of Russian language proficiency (B1-C1), weak motivation, and difficulty in mastering a number of disciplines due to the complexity of studying them distantly.

The most effective course was the study of the discipline "Methods of teaching Russian as a foreign language", the services of Microsoft Office 365 allowed us to efficiently and clearly review all the material studied in this course. One of the main problems, we suppose, was the difficulty of organizing a discussion, discussing methodological problems in the classroom with Chinese students. Written assignments by students from China were traditionally performed at a fairly high level, and oral communication was not successful enough. If during the classroom sessions it was possible to engage students in a conversation through active individual and collective contact work, then during online communication this task was difficult to accomplish.

A number of difficulties arose for foreign students from Turkmenistan when studying such sections of the modern Russian language as "Morphemics. Word formation", disciplines "Historical grammar", "Old Slavic language". On the one hand, these disciplines are quite difficult for foreign students to study, on the other-the presentation of the material using virtual services is quite problematic. Special fonts with a large number of diacritics and obsolete letters do not allow the use of virtual whiteboards for online explanations of the material and online recordings by the teacher and the collective work of students during distance learning. It was quite problematic to conduct high-quality current control. As you know, current control plays an important role in RFL-teaching, it allows the teacher to identify mistakes made by students, identify gaps in knowledge, and, accordingly, adjust the learning process. When conducting the final control, the proctoring system was successfully used, but it was impossible to use this system in the vast majority of classes. As a result, the current oral and written control did not show real results of the students' mastering of the studied material. The survey showed that $93 \%$ of foreign students and $100 \%$ of teachers of the disciplines "Old Slavonic Language", "Historical Grammar", "History of the Russian Literary language" have a negative assessment of distance learning in these subjects.

All the above difficulties were also observed in the process of teaching foreign students of non-philological profile of the first year of study with the lowest level of proficiency in the Russian language A2. In addition, it took much longer to study a certain amount of material in a virtual environment than in a contact form of work. The lack of direct "live" control on the part of the teacher led to the fact that students were often distracted, reacted slowly to the teacher's requests, and completed writing tasks within a long period of time.

Thus, we can identify three main criteria that affect the quality of teaching Russian language courses to foreign students in a distance format using a virtual educational environment: the level of Russian language proficiency, motivation and the language section/discipline being studied. An important role is played by the individual psychological and pedagogical characteristics of the student's personality. So, many students and undergraduates quickly and easily switched to a new virtual learning format and said that they prefer to continue studying in this format. Some students initially treated 
learning in a virtual format in a negative way, and later, as they mastered the services and the specifics of working in them, they determined that both online and offline learning was possible. A part of the contingent after the experiment with the distance learning format stated that they had identified the classroom format of work as the only acceptable one.

The fall semester of the 2020/21 academic year at the Institute of Philology, Journalism and Intercultural Communication of the Southern Federal University started with the application of various models for the inclusion of a virtual educational environment in the learning process of foreign students. The leading criterion for choosing a model for using a virtual educational environment was the possibility/impossibility of a student attending classroom classes. During the winter holidays of 2020, many foreigners left for their homeland and could not return back, many new foreign students entered the university in the summer of 2020 in a distance format.

As an experiment, study groups with all the students being present in Russia were transferred to the following model: lectures in a distant format with the use of a virtual educational environment, practical - in full-time; groups in which some students were in Russia, some - abroad-according to the model: lectures in a distant format, practical-in fulltime with online broadcast in a virtual educational environment. The groups with all the students being abroad studied according to the model of full distance learning with the use of a virtual educational environment.

In contrast to the previous semester, when students who had been studying with a teacher for six months or more were transferred to the distance learning format, in the new semester, teachers in groups had new students with whom they were not familiar. Considerable importance when working with foreign students is played by taking into account the individual characteristics of the student, the psychological and pedagogical portrait of the individual. The contact form of the work allows the RFL-teacher make a psychological and pedagogical portrait of each of the students quickly, to determine the ability to learn a foreign language, the individual characteristics of the assimilation of language material. Training in a virtual educational environment has shown that these processes take much longer, become more time-consuming, and require more professionalism.

During the installation stage of the experiment on the introduction of a mixed learning model, conducted in September 2020, the following was revealed by the questionnaire method: at the initial stage of the implementation of this model, which combines elements of traditional learning and learning in a virtual educational environment, many foreign students located in Russia abandoned the online format in favor of classroom work. Thus, among Chinese students and undergraduates who came to the Southern Federal University to study Russian, supporters of traditional forms of teaching initially turned out to be $100 \%$ (all 47 Chinese students preferred to study in an offline format). Similar indicators were given by the survey of students from Turkmenistan. Out of 96 Turkmen students, 87 people $(91 \%)$ were in favor of studying in the traditional classroom mode, while only 9 people $(9 \%)$ were in favor of the online format, while all those who were in favor of studying in a virtual educational environment, due to the circumstances, were outside of Russia and could not start working in the classroom mode. These data correlate with those established on the basis of a survey of students from Latin America, Greece, Mongolia, and the Congo. Out of 33 students and undergraduates from the above countries and regions, only 8 students located outside the Russian Federation were in favor of studying in a virtual educational environment, and online training was the only possible option for them, while $100 \%$ of foreign students in Rostov-on-Don preferred classroom work.

However, already at the stage of the training stage of the experiment, which included elements of remote work, the attitude of foreign students to the virtual model changed significantly. Foreign students appreciated the advantages of the mixed learning model, 
which includes the traditional format of work in the classroom with parallel translation in a virtual educational environment. An increasing number of foreign students who were in Rostov-on-Don and studied in the classroom, in the course of their studies, began to switch to a mixed learning model. Foreign students and undergraduates positively assessed, first, the very opportunity to study both in the traditional format, in the classroom, and with the use of elements of work in remote mode. Secondly, an important factor was the opportunity to record the lesson for further independent work with the material. Third, the advantage of the mixed model was the ability to independently make a choice in favor of the offline or online format, as well as the ability to quickly switch from the traditional model to the virtual one, which is exactly what the mixed learning model implies.

The task of the control stage of the experiment was to obtain data after the training stage. The survey conducted during the control stage of the experiment showed that at the moment, $74 \%$ of the total number of foreign students studying Russian at the Southern Federal University recognize the most convenient and effective model, which provides for both offline and online training (131 people out of 176 surveyed participants in the experiment). 45 students (including 39 students from Turkmenistan) remain supporters of the exclusively traditional model, which provides for offline training, which is $26 \%$ of the total number of respondents.

The experimental data obtained by introducing a blended learning model into the practice of teaching Russian as a foreign language at Southern Federal University are presented in the table below:

Table 1. The experimental data obtained by introducing a blended learning model into the practice of teaching Russian as a foreign language at Southern Federal University

\begin{tabular}{|c|c|c|c|c|c|}
\hline \multicolumn{6}{|c|}{$\begin{array}{l}\text { Experimental results on introducing a blended learning mo } \\
\text { of teaching Russian as a foreign language at Southern Fe }\end{array}$} \\
\hline \multicolumn{6}{|c|}{ Inception phase of the experiment } \\
\hline Country & $\begin{array}{c}\text { Number } \\
\text { of } \\
\text { students }\end{array}$ & $\begin{array}{l}\text { Students } \\
\text { preferred } \\
\text { traditional } \\
\text { learning }\end{array}$ & $\begin{array}{l}\text { Number of } \\
\text { students } \\
\text { present at } \\
\text { Southern } \\
\text { Federal } \\
\text { University }\end{array}$ & $\begin{array}{l}\text { Students } \\
\text { preferred } \\
\text { blended } \\
\text { learning }\end{array}$ & $\begin{array}{l}\text { Number of } \\
\text { students } \\
\text { present at } \\
\text { Southern } \\
\text { Federal } \\
\text { University }\end{array}$ \\
\hline China & 47 & 47 & 47 & 0 & 0 \\
\hline Turkmenistan & 96 & 87 & 87 & 9 & 0 \\
\hline Mongolia & 2 & 1 & 1 & 1 & 0 \\
\hline The Congo & 1 & 1 & 1 & 0 & 0 \\
\hline Greece & 1 & 1 & 1 & 0 & 0 \\
\hline Colombia & 14 & 10 & 10 & 4 & 0 \\
\hline Ecuador & 9 & 8 & 8 & 1 & 0 \\
\hline Venezuela & 6 & 4 & 4 & 2 & 0 \\
\hline \multirow[t]{2}{*}{ Total: } & 176 & 159 & 159 & 17 & 0 \\
\hline & $100 \%$ & $90 \%$ & $90 \%$ & $10 \%$ & $0 \%$ \\
\hline \multicolumn{6}{|c|}{ Control phase of the experiment } \\
\hline Country & $\begin{array}{l}\text { Number } \\
\text { of } \\
\text { students }\end{array}$ & $\begin{array}{c}\text { Students } \\
\text { preferred } \\
\text { traditional } \\
\text { learning }\end{array}$ & $\begin{array}{l}\text { Number of } \\
\text { students } \\
\text { present at } \\
\text { Southern } \\
\text { Federal } \\
\text { University }\end{array}$ & $\begin{array}{c}\text { Students } \\
\text { preferred } \\
\text { blended } \\
\text { learning }\end{array}$ & $\begin{array}{l}\text { Number of } \\
\text { students } \\
\text { present at } \\
\text { Southern } \\
\text { Federal } \\
\text { University }\end{array}$ \\
\hline China & 47 & 4 & 4 & 43 & 43 \\
\hline
\end{tabular}




\begin{tabular}{|c|c|c|c|c|c|}
\hline Turkmenistan & 96 & 39 & 39 & 57 & 48 \\
\hline Mongolia & 2 & 1 & 1 & 1 & 0 \\
\hline The Congo & 1 & 1 & 1 & 0 & 0 \\
\hline Greece & 1 & 0 & 0 & 1 & 1 \\
\hline Colombia & 14 & 0 & 0 & 14 & 10 \\
\hline Ecuador & 9 & 0 & 0 & 9 & 8 \\
\hline Venezuela & 6 & 0 & 0 & 6 & 4 \\
\hline Total: & 176 & 45 & 45 & 131 & 114 \\
\cline { 2 - 6 } & $100 \%$ & $26 \%$ & $26 \%$ & $74 \%$ & $87 \%$ \\
\hline
\end{tabular}

Experimental results given in the table clearly demonstrate the dynamics of changes in the attitude of foreign students towards the blended learning model. It is for sure a fact of utmost importance that $87 \%$ of the total number of the foreign students present at Southern Federal University (114 students out of 131) preferred blended learning during the experiment and consciously opted for the blended learning model that combines offline and online education. Therefore, it is reasonable to say that the mixed model of teaching Russian as a foreign language has proved its effectiveness and has been recognized by most of the students.

\section{Discussion}

The second decade of the 21st century was a time of active discussion of the possibilities of the virtual educational environment in RFL-teaching. However, despite the relevance of this topic, large-scale experiments on the introduction of a virtual educational environment in educational institutions of various levels have not been conducted. According to year 2019 research, it was assumed that the share of online education in Russia in 2021 will be only 2.6\%: "for most Russians, distance learning is still a novelty, but every year it becomes more popular. Today, the turnover of the Russian online education market is growing faster than in most countries - by $20-30 \%$ per year (compared to $5-30 \%$ in the world) ... By 2021, the market share of online education in Russia will be $2.6 \%$... [20]

"The year 2020 has radically changed the situation in the global education system. The virtual educational environment has passed a large-scale testing with $100 \%$ translation of the educational process into a remote format. Russian language training for foreign students was conducted with varying degrees of inclusion of various services for creating a virtual environment.

It seems appropriate to identify the following models for the introduction of a virtual educational environment in the RFL-teaching:

1. The traditional classroom model of learning with the use of individual elements of the virtual educational environment in order to intensify the learning process both in the classroom and out-of-class work.

2. The traditional classroom model of training with the use of separate open online courses, both developed by teachers who implement the educational process in an educational institution, and paid/free courses developed by specialists of third-party organizations.

3. The combination of the traditional classroom model of learning with an innovative model of learning in a virtual educational environment: lectures are conducted virtually, practical classes are held in the format of contact work, or one part of the disciplines is conducted in the classroom, the other-in a virtual environment.

4. Combining the traditional classroom learning model with an innovative one, which involves online broadcasting of all classes in a virtual space, which will allow you to study both full-time and remotely. 
5. An innovative learning model that assumes $100 \%$ of classes are conducted in a virtual educational environment.

Personal experience of teaching Russian as a foreign language in a distance format to students from China, Mongolia, Turkmenistan, Congo, Greece, and Latin American countries studying in the bachelor's and master's programs of the Southern Federal University in the areas of training 44.03.05 - "Teacher Education" and 45.03.01 "Philology", allows us to draw the following conclusion: at the present stage, the optimal model is a mixed learning model that combines traditional teaching in the classroom with parallel online broadcasting of classes in virtual space. This model allows, firstly, to master the necessary competencies not only for students studying in the format of contact work, but also for those students who, due to various circumstances, cannot be present in the classroom. Secondly, such a flexible model allows the student to make a choice between traditional and innovative models, leaving him the opportunity to switch from one model to another directly in the learning process. Undoubtedly, the large-scale implementation of this model in educational institutions will require the availability of special equipment in all classrooms and a certain training of the teaching staff.

\section{Conclusions}

Thus, in the coming years, we will be able to observe the introduction of various models of teaching Russian as a foreign language within a virtual educational environment. The choice of a particular model will depend on both extralinguistic and linguistic factors: the epidemiological situation in the world, financial capabilities of the educational institution, desire to attract a large number of foreign students, the level of Russian language proficiency of students, the complexity of certain disciplines in terms of presenting material virtually, etc. Various combinations of models are possible in order to optimize the educational process, to make it as effective as possible, to achieve the best results in the development of the Russian language by foreign students.

\section{References}

1. F. Martin, T. Sun, C.D. Westine, Computers and Education, December 2020 19, https://www.sciencedirect.com/science/article/abs/pii/S0360131520302074 (last accessed 2021/02/09).

2. A. Kukulska-Hulme, Mobile Learning for Quality Education and Social Inclusion (UNESCO IITI, Moscow, 2010).

3. A. Bilyalova, Prosedia. Social and Behavioral Sciences 237, 175-181 (2017).

4. A.I. Gorozhanov, Educational virtual platform for learning a foreign language: problems of design and development (MSLU, Moscow, 2016).

5. E. Southgate, S.P. Smith, C. Cividino, S. Saxby, J. Kilham, G. Eather, J. Scevak, D. Summerville, R. Buchanan, C. Bergin, International Journal of Child-Computer Interaction. March 2019 19, 19-29 (2019).

6. I. Dokukina, J. Gumanova, Social and Behavioral Sciences 169, 542-546 (2020).

7. I.B. Gotskaya, V.M. Zhuchkov, A.V. Korablyov, Analytical entry "Choosing a distance education system" (RSPU, Saint Petersburg, 2010).

8. I.L. Novokreschenova, Using the conference platform Zoom as a tool for teaching RFL The dialogue of languages and cultures within a modern educational field, International scientific and practical conference proceedings, 68-70, Voronezh, 2020. 
9. D. Pal, V. Vanijja, Perceived Usability Evaluation of Microsoft Teams as an Online Learning Platform During COVID-19 using System Usability Scale and Technology Acceptance Model in India, Children and Youth Services Review, October 2020, https://www.sciencedirect.com/science/article/pii/S0190740920313992 (last accessed 2021/02/13).

10. S.A. Gerasimova, I.V. Makarova, Using the educational platform ISpring as a tool for teaching a foreign language. The Magic of Innovation: new dimensions in Linguistics and Linguodidactics, Collection of Scientific Papers, 293-300, Moscow, 2017.

11. A. Patricia, College Students' Use and Acceptance of Emergency Online Learning Due to COVID-19, International Journal of Educational Research Open, September 2020, https://www.sciencedirect.com/science/article/pii/S266637402030011X (last accessed 2021/02/15).

12. P.D. Maclntyre, T. Gregersen, S. Mercer, Correlations with stress, wellbeing and negative emotions. System 94, November 2020, https://www.sciencedirect.com/science/article/pii/S0346251X20307120 (last accessed 2021/02/16).

13. Chin-Hsi Lin, M. Warschauer, The Modern Language Journal 99 (2), 394-397 (2015).

14. I.V. Nefedov, K.A. Popova, Proceedings of Southern Federal University. Philology 3, 170-178 (2016).

15. A. Bogomolov, Models of virtual environment in teaching a foreign language, http://docplayer.ru/28402203-Obrazovatelnyh-informacionno-kommunikacionnyh.html (last accessed 2021/02/16).

16. I.V. Nefedov, The World of Russian Word 4, 61-71 (2019).

17. S.V. Korostova, I.V. Nefedov, Conventional and innovative content as the basis of project activities in the course of Russian as RFL Russian Studies 1 (18), 85-96 (2020).

18. I.V. Nefedov, M-learning $u$ E-learning as the basis for developing modern academic programs on RFL teaching methods, X International Sevastopol Cyril and Methodius Reading: Collection of scientific papers, 186-192, Shiko. Sevastopol, 2016.

19. I.V. Nefedov, Philology, Rostov-on-Don 2 168-179 (2018).

20. Sh. Khag, Online education: can the Internet replace school? https://www.rbc.ru/trends/education/5de126b59a79475b973cd3d3 (last accessed 2021/02/18). 